\title{
FINANCING OF PERMANENT WORKING CAPITAL IN AGRICULTURE ${ }^{1}$
}

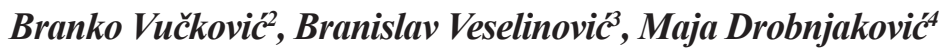 \\ Summary}

In this paper, we attempted to present the problem of establishing adequate structure of financing medium agricultural enterprises and to point out the necessity for permanent working capital in those agricultural enterprises which can't cover fixed assets, long-term placements and portion of inventories (raw material and spare parts, production in process) with own equity and long-term sources of financing. For the purpose of analysing adequate structure of financing medium agricultural enterprises, we will use one of the most popular methods, such as case study and ratio analysis. Results of the research show that in primary agricultural production, next to standard long-term investment loans and short-term loans for investment in agricultural production, there is a necessity for financing in the permanent working capital which could assist continuity of production process and enable conditions for more profitable business in agriculture. It also should be noted that real and book value on this level of permanent working capital differs substantially.

Key words: agriculture, financing, permanent working capital, permanent inventory, profitability.

JEL: $Q 12, Q 14, G 21$.

\section{Introduction}

Rules of financing represent the norms and standards based on relations between fixed and current assets and own (long-term) and borrowed (long-term, medium-term and short-term) sources of financing in liabilities, which should be respected in terms of establishing stable, lucrative and profitable business operation.

1 This work represents sequel of research based on a $\mathrm{PhD}$ thesis "Financial position and profitability of agricultural enterprises", which includes period 2009-2013. (Vučković, 2016).

2 Branko Vučković Ph.D., Vojvodjanska Bank NBG Group, Sonje Marinković street no. 1-3, 25000 Sombor, Serbia, Phone: +381 25465 000, E-mail: vule.sombor@gmail.com

3 Branislav Veselinović Ph.D., Full Professor, University Business Academy in Novi Sad, Faculty of Economics and Engineering Management, Cvećarska street no. 2, 21000 Novi Sad, Serbia, Phone: +381 21400 484, E-mail: brane1952@gmail.com

4 Maja Drobnjaković M.A., Assistant, University Business Academy in Novi Sad, Faculty of Economics and Engineering Management, Cvećarska street no. 2, 21000 Novi Sad, Serbia, Phone: +381 21400 484, E-mail: majadnovisad@gmail.com 
Source of finance structure is one of the most important parameters which contribute to enterprise's profitability. There are a number of theories about relations between financial indebtedness and profitability, regarding the activity of given enterprise (agricultural activity, especially primary agricultural production has certain characteristics). Foundation of these theories is based on analysis what optimal financing structure should be and one that provides best results of business which are measured through indicators of profitability, liquidity as well as overall development of the enterprise. Lower the indicator of indebtedness, higher are own sources of financing and it can be presumed that enterprise fulfils the prerequisite for profitable business.

Establishing adequate structure of financing in agricultural enterprise represents quite a complex problem. Horizontal rule of financing (so called balance rule in the narrow sense) observes the relation between fixed assets and long-term sources of financing. When we talk about enterprises in primarily agricultural production, it is necessary to imply on their need for securing certitude, by which we mean financing fixed assets with own capital.

Based on perennial analysis of the agricultural sector, we can deduct general conclusion that agricultural enterprises should rely on long-term sources of financing exclusively in starting years of the investment cycle. Structuring the liabilities of the balance sheet, which is a fundamental task of financial management in one's enterprise, is partly conditioned by ownership structure and legal form of the enterprise. Based on continuous analysis of the financial state of the enterprise, financial management decides of ways for gathering sources of financing. This kind of analysis should provide ananswer to question whether resources and sources of financing are harmonised by volume and maturity (Veselinović, Vunjak, 2014). Each new financial result changes financial structure of the enterprise, where profit represents a source of increased own sources of financing in liabilities in the balance sheet (increase in group 34 - Retained profit leads to increase in class 3 Capital). And vice versa, withdrawal of profit by owner(s) or in payment of dividends in stock-companies, leads to a reduction of own sources of financing.

During the assessment of own sources of financing, the principle of security and balance rule in a broader sense implies that, other than fixed assets and a portion of permanent working capital, inventory should also be covered with long-term sources of financing (own equity or long-term loans).

The necessity for a high share of tangible assets in the structure of total assets in the balance sheet (land and equipment), as well as low return on assets rate, consequently affects on increased necessity of agricultural enterprises for investment loans for longer periods of time (approximately 7-10 years).

\section{Literature Review}

In a time of increased business sensitivity and emergent of the global crisis, it is of utmost importance to offer significantly favourable credit requirements to agricultural enterprises and in that way stimulate investments in the agricultural business. On the 
other hand, financial support for agriculture through the agrarian budget is not enough for its sustainability. So, lack of the financial sources is the key factor that limits the effective use of agricultural resources, with the countries in the transition, as well as developed countries. Despite rich tradition and natural resources, agricultural enterprises in Serbia are disabled when it comes to financial investment in new technologies, equipment, knowledge and innovation, and therefore, their competition is seriously impaired, not only in international but the local market as well. Of course, financial mix in the agricultural sector is significantly different from the financial mix in other industries, due to its specific features (Veselinović, Drobnjaković, 2014).

Some researches imply that main factors which influence on the net profit of agricultural enterprises are education, size and typology, specialisation and level of state payments. Key factors which influence on asset turnover ratio in DuPont model are asset's age and efficiency in the management of different forms of property (Detra, Mishra, 2012). Changes in profitability of agricultural enterprises can be observed as consequences of changes in quality and quantity of production factors, or measurable changes in relative prices (O’Donnell, 2010).

Katchova (2010) analysed the characteristics that agricultural lenders need to consider when evaluating farmers' loans. She pointed out that older farmers and larger farms are less likely to experience financial stress while hobby farms and livestock farms are more likely to experience financial stress.

Mishra, Moss and Erickson (2009) suggested that government payments impact the profit margin and affect value of farm assets in particular farmland values but not asset turnover ratio.

Petrick and Kloss (2012) concluded that relationship between farm financial indicators and the estimated shadow prices of capital varies considerably across countries and sectors.

Measures of sectoral investment and capital stocks are essential in applied economics research (Daidone, Anriquez, 2011). Butzer, Mundlak and Larson (2010) pointed out that capital is a fundamental component of agricultural production, and that the accumulation of capital is key to growth in agriculture. Unfortunately, cross-country data sets on agricultural fixed capital are rare.

In this research, special attention is focused on the analysis of needs for permanent working resources (fixed inventories) in the scope of selected enterprises and financing of the mentioned. Therefore, permanent working capital represents part of inventories which is permanently kept at a certain level for maintaining continuity of business operations (concept Going Concern). If agricultural enterprises do not possess enough own sources of financing, they can acquire it either through prolongation of obligations to suppliers or bank loans (in the case of agricultural enterprises in Serbia, this is the common case). Loans for permanent working capital with a repayment period of 36-48 months should be a source for financing fixed inventories. 


\section{Defining the research subject}

Looking at needs of primary agricultural production and structure of financial reports, it shows that agricultural production has a need to finance part of its assets in inventories from fixed capital, and in case that is not possible, loans for permanent working capital with long repayment periods.

Beside fixed assets, enterprises in agricultural production also have certain working assets which, fundamentally, have permanent characteristics (fixed inventories).

Table 1. Structure of inventories in enterprises of primarily agricultural production

\begin{tabular}{|l|}
\hline 1. Raw material, spare parts, tools and inventories \\
\hline 2. Work in progress and services in progress \\
\hline 3. Finished products \\
\hline 4. Merchandise \\
\hline 5. Fixed assets for sale \\
\hline 6. Advances for services and inventories \\
\hline
\end{tabular}

Source: Work of authors.

A portion of these inventories, in transitioning form, is continuously featured in a certain quantity. Those fixed inventories can be defined as the minimum level of permanent working capital. In the sector of agriculture, those consist of necessary raw material for production. Due to optimal sowing structure, we can ascertain that investments in primarily agricultural production are continuous through the year (due to its specificity). For those reasons, part of working capital in limits of material and spare parts, and production in progress should be considered permanent working capital.

Investments in agriculture last for longer periods of time, up to 12 months, until finished product is made, which ultimately demands that in agriculture certain amount of working capital is kept in form of finished products in inventories. On the other hand, the process of investment implies hiring of work force, and that implies that certain level of working capital is kept in form of money (all in order unobstructed cycle of production).

Author's estimation is that investments in early crops in primarily agricultural production is around $30 \%$ of total investments, while investments in late crops are about $70 \%$ of total investments (so, $70 \%$ of other business expenses is financed from expected yields achieved on autumn crops, that is, in that percentage should working capital inventories or cash be kept).

The problem of loans for agriculture on long-terms is caused by fact that creditors for such loans demand collateral in form of property mortgages. Agricultural enterprises in development are already in burden with fixed assets. During lending of permanent working capital, it should be possible to monitor overall level of inventories during the total period of lending and define collateral dependence on book level of inventories (disregarding the form of inventories). 
Next to investment loans and loans for permanent working capital, enterprises from primary agricultural production are financed also with short-term loans intended for investing in the production cycle and finished product inventory (in order to wait for the optimal price and achieve best results). Short-term loans for this purpose most commonly have 12-18 months repayment plan and follow entire production process or part of the cycle of asset turnover in enterprises in primary agricultural production.

In the past 7-year period, prices of primary agricultural products have recorded distinct growth, up to $100 \%$ in relation to prices in the harvest. The price of wheat in July 2010 was 10.30 RSD, while in December of the same year had reached 25.15 RSD. In August of 2013, the price was 15.00 RSD and in January of 2014 price was 27.50 RSD. The price of corn in year 2013/2014 has in just 90 days (October - January) increased from 12.60 to 24.70 RSD. Soybean has also had high price fluctuation in given period (www.proberza. co.rs). Since 2014, this trend in price growth was less distinctive, but all this has caused growing need for keeping agricultural products until the moment of achieving best market price, as well as prolonging turnover asset cycle in agriculture (in some moments, up to 7 months after finished cycle of production), and during the time of waiting for the best price, new investments in production are necessary for the following year. In that case, permanent working capital is considered fixed inventory which is necessary for enabling continuity of regular production cycle.

Research subject in this paper is the development of intersection of the need for permanent working capital in selected agricultural enterprises which are not in possibility to finance tangible assets, property under construction, long-term investments and a portion of fixed inventory with own capital and long-term loans.

\section{Defining the research goal}

The research goal in this paper is to define whether are cycles of agricultural production in alignment with cycles of financial reports compilation of agricultural enterprises, as well as the more accurate find of which portion of inventories in balance sheet can be concerned as permanent working capital and how it is financed.

If an agricultural enterprise can't finance its fixed assets and portion of inventories with own capital or long-term loans, which is a common situation with agricultural enterprises in Serbia, it should search for a solution in loans for permanent working capital with a repayment period of 36-48 months as a source of financing portion of inventories. More accurately, repayment period can be defined regarding the profitability of the certain enterprise. Agricultural enterprises who did position their fixed assets and their sources of financing should keep the profit for coverage of permanent working asset.

On the other hand, research goal is to question whether agricultural enterprises who do possess enough own capital have, at the same time, need for permanent working capital, while gaining significantly improved profitability in comparison with enterprises who are financed with short-term sources. 


\section{Defining the hypothesis of research}

Following is defined general hypothesis:

$\mathrm{H}_{0}$ : Financing permanent working capital from own sources and other long-term sources contributes to increased profitability of primary agricultural production enterprises.

\section{Defining the methodology of research}

In the scope of this research, we used method of case study and mathematical method, and also experiential (empirical) method. In the scope of the case study, we performed analysis of three agricultural enterprises, PP Ratkovo, Agroplod Stapar and Agrooffice Bački Brestovac (which operates on the territory of Zapadnobački county for the period of 2013-2015). When we talk about quantitative (mathematical) analysis, we applied ratio analysis (calculating liquidity ratio, profitability, indebtedness and efficiency ratio, as well as the ratio of longterm financial stability). Results of ratio analysis were commentated from internal aspect (ascertainment of up, down or stagnation tendencies of business), and from external aspect (in relation to activity in which three observed enterprises operate).

During analysis, we also used parsing and comparison method, as well as analysis of the time series (trend line based on analysis of chronological group data of selected enterprises of primary agricultural production).

Also, we used descriptive method, as well as experiential (empirical) method, during interpretation of given results, recognising specific and isolated cases, and interpreting causes of identified deviations. In this segment of the research, commentating on the specificity of agricultural activity will be of great importance.

In the end, we should mention that in the post time period (since the period of the research) few minor corrections in official financial reports have been made. These corrections are performed in accordance with the International Accounting Standards and Laws of Accounting. However, mentioned corrections of certain positions in balance have not had an impact on this research.

\section{Analysis of the results}

This research includes analysis of 3 medium agricultural enterprises which operate on Territory of Zapadnobački County, in the span of 3 years (2013-2015). Enterprises in question belong to large systems which are export-oriented or have a manufacturing industry.

Based on researches so far (Vučković, 2013; 2014; 2016), we came to the conclusion that the most profitable agricultural enterprises in Vojvodina had EBITDA margin above $30 \%$. Also, we've reached the conclusion that the most profitable enterprises in finance source structure had $70-88 \%$ of own sources of financing (equity). This enables them to have profit in the range of 22-47\% in observed period of time (Vučković, 2016).

Based on previous research, we can conclude that in Serbian economy in given time period, extraneous sources of agriculture financing is an extremely expensive category (Vučković, 
2016). Previous research has also implied that significant part of the primary agricultural production is financed on the burden of the suppliers, which is an extremely expensive source of financing or using loans in commercial banks, which also affects profitability in a negative sense. As one of the conclusions, which imposes once again, is that well-capitalized enterprises can achieve high profitability. On the other hand, worst results are shown in enterprises that use short-term sources of financing (at the burden of the suppliers or using short-term bank loans).

During defining permanent working capital that should be financed from permanent sources we started with two assumptions (first is based on experience and statistics of an expert in agriculture about total investments in the agricultural production of crop plants). In this paper, it is defined that all investments which follow the process of production during one year, and before final sale and payment of finished products, should be considered permanent working capital.

When we talk about raw material and production in progress, author's estimation is that total expense in wheat is 650 EUR, while permanent working capital is $21 \%$ of that amount id est. 135 EUR (beginning phase of investment, which implies usage and dispersal of mineral fertiliser and plowing). In estimations of minimum needs for permanent working capital, we observed necessarily repeated expenses in the same crop during one year, considering that all crops were based on spring sowing.

About corn production, authors estimate that total amount of permanent working capital is around 190 EUR, which is $26 \%$ of total expenses, which are 708 EUR per hectare. At the production of sugar beet, authors estimate that amount of permanent working capital is 260 EUR per hectare, which is $23 \%$ of total expense in this crop which is 1,130 EUR per hectare.

With soybean production, authors estimate that permanent working capital is at $154 \mathrm{EUR} / \mathrm{ha}$, which is about $28 \%$ of total expenses, which is $536 \mathrm{EUR} / \mathrm{ha}$ in the production of this crop.

Sunflower production - total expense is $557 \mathrm{EUR} / \mathrm{ha}$, from which we estimate that expense in permanent working capital is $154 \mathrm{EUR} / \mathrm{ha}$ (around 27\%).

Mentioned above are defined costs of production of crops based on perennial statistics of an expert witness, and authors attempt to define the minimal necessary amount of permanent working capital in each agricultural crop.

The second assumption for determination of the necessary amount of permanent working capital is defined based on annual financial reports. Analysis of total assets and equity and liabilities was performed with the goal of achieving conclusion whether are empiric amounts and book amounts of permanent working capital in these enterprises match. Data extracted from accounting statements of current inventories and investment in agricultural production from annual financial reports are:

1. Material, spare parts, tools and inventories

2. Work in progress and services in progress 
These items represent the part of inventory which is permanently placed in process of production of agricultural products. While one part is in form of uncollected finished product, by the end of the year agricultural enterprises invest once more in material, artificial fertiliser and services of its dispersal and plowing. So, the cycle of production is finished, but the cycle of the working capital is not because the collection of finished products is not carried out at most of the manufacturers who wait for the right moment of sale to achieve most profitable effects. Analysing data from annual financial reports, the share of permanent working capital ranged differently in all three enterprises. PP Ratkovo in the year 2013 had a share of 53\% due to intensive investment in sugar beet, while in the year 2015 that share was at $27 \%$ due to the fact that dominant crop was wheat.

At enterprise PP Agroplod Stapar (largest part of the production is based on wheat, corn and soy), the share of permanent working capital in total inventory dropped from $32 \%$ in the year 2013 to $22 \%$ in 2014 and 2015.

Enterprise Agrooffice in 2015 had share of $23 \%$ in relation to total inventory, while in previous years, due to significant investments in vegetables that share was far more.

From the group of observed enterprises, we focused on three enterprises with different needs for permanent working capital, away of financing and effects in which own and borrowed sources of financing affect profitability. Special attention is focused on the analysis of the need for permanent working capital in agricultural enterprises which don't have enough own sources of financing. In practice, that capital is substituted using short-term sources of financing, which however impairs total profitability.

PP Ratkovo is an enterprise which during observed period covers with own capital entire fixed assets, and almost completely working capital. With that structure of finance sourcing, this enterprise in this period achieves gross profit above $50 \%$, and in the last two years of period observed 54\%, EBITDA margin at 32-36\% in year 2015, while net margin in last year of the observed period is at $24 \%$, which is extraordinary indicator for this activity. In analysed period, the enterprise had no investments, but an entire profit turned into fixed capital. By looking into the structure of sources within this enterprise, it is evident that this enterprise does not show the need for permanent working capital.

Table 2. Analysis of short balance sheet of PP Ratkovo

\begin{tabular}{|l|r|r|r|}
\hline \multicolumn{1}{|c|}{ YEAR } & \multicolumn{1}{c|}{$\mathbf{2 0 1 3}$} & \multicolumn{1}{c|}{$\mathbf{2 0 1 4}$} & \multicolumn{1}{c|}{$\mathbf{2 0 1 5}$} \\
\hline FIXED ASSETS & 1.113 .858 & 1.080 .063 & 1.040 .347 \\
\hline WORKING CAPITAL & 502.588 & 578.215 & 686.291 \\
\hline Inventories & 172.825 & 215.034 & 260.775 \\
\hline material, spare parts, tools and inventories & 4.514 & 5.822 & 4.954 \\
\hline production in progress and service in progress & 87.862 & 78.230 & 77.415 \\
\hline other inventories & 80.749 & 130.982 & 178.406 \\
\hline Other working capital & 329.763 & 363.181 & 425.516 \\
\hline DEFERED TAX ASSETS & 33.873 & 12.720 & 5.844 \\
\hline
\end{tabular}




\begin{tabular}{|c|c|c|c|}
\hline YEAR & 2013 & 2014 & 2015 \\
\hline Total assets & 1.650 .319 & 1.670 .998 & 1.732 .482 \\
\hline EQUITY & 1.574 .451 & 1.637 .449 & 1.722 .542 \\
\hline LONG-TERM PROVISIONS AND LIABILITIES & 32.031 & 6.745 & 1.879 \\
\hline SHORT-TERM LIABILITIES & 43.837 & 26.804 & 8.061 \\
\hline Total equity and liabilities & 1.650 .319 & 1.670 .998 & 1.732 .482 \\
\hline
\end{tabular}

Source: Balance sheet of the PP Ratkovo, for the period of 2013-2015.

Graph 1. Analysis of the structure of total assets and total liabilities in PP Ratkovo

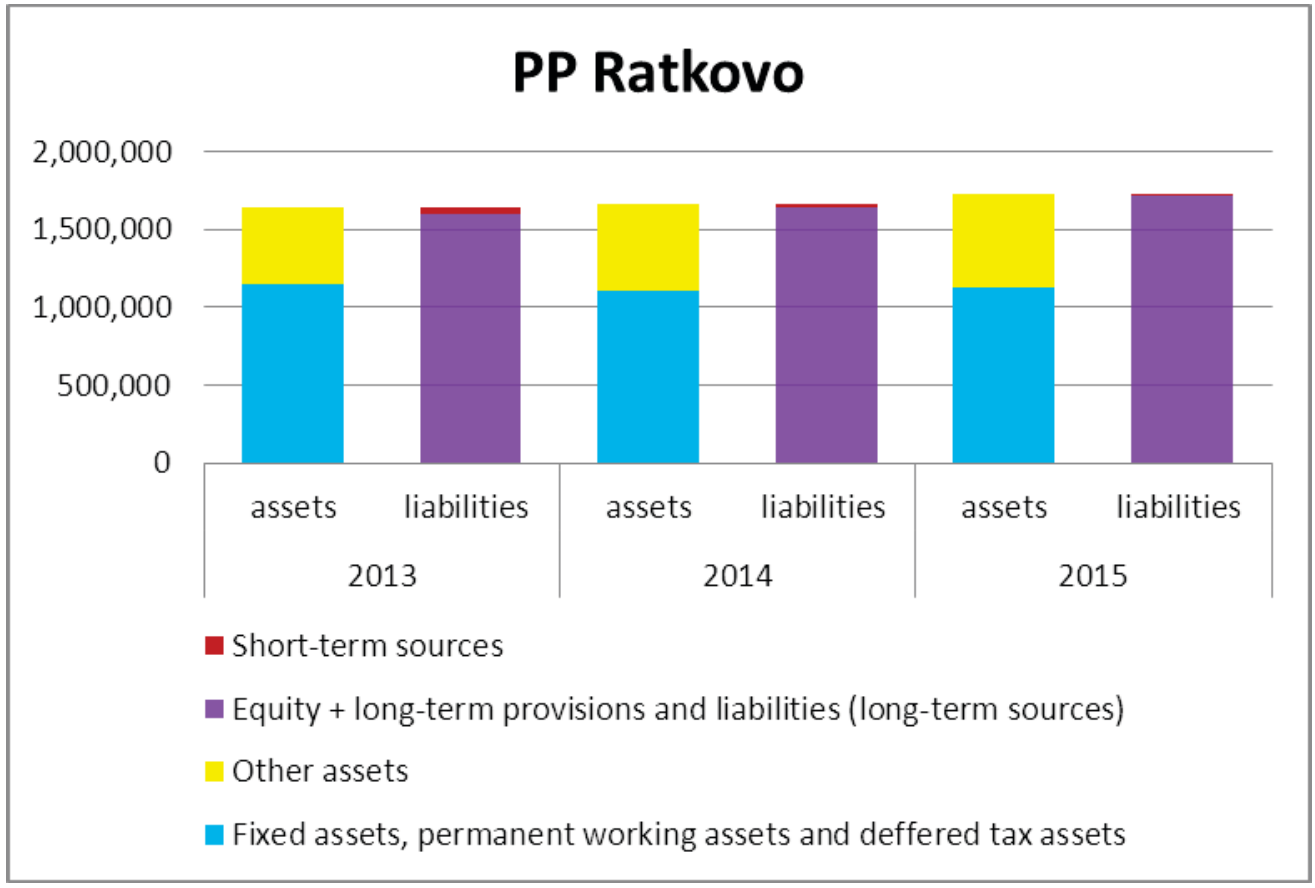

Source: Work of authors.

In the last observed year, this enterprise is almost entirely financed from own permanent sources, which have reached the level of $99.4 \%$. In this enterprise, liquidity ratios have also increased substantially from 21 to 85 .

Enterprise Agroplod Stapar has, in the observed time period, changed its structure of fixed assets and sources of financing. In the year 2013 fixed assets have been covered with own capital almost entirely. In the next years, the long-term loan has been used for covering a certain amount of deferred tax assets, which can be subsumed under long-term financial investment, as well as inventories which are treated as a minimum level of necessary required inventory for unobstructed production (so-called permanent working capital).

Enterprise Agroplod Stapar has weaker asset source structure from PP Ratkovo because it is in continuous investment, which is shown through fixed asset increase. This enterprise 
did not have enough long-term financing sources to cover permanent working capital in the year 2013. In the year 2014, there has been a change in financing sources structure, in such way that profit was transformed into capital, and this enterprise was able to cover fixed assets from own sources entirely, and with long-term loans has covered portion of the longterm investment and permanent working capital. Also, in 2015, there has been changing in structure, when part of the profit from previous year was used to increase capital or own long-term sources of financing, which did now cover, beside fixed assets, portion of deferred tax assets, but with long-term loan this enterprise still has not been able to cover investments which are considered long-term investment in agriculture and they reimbursed it with more expensive short-term loans. In this case, in enterprise Agroplod Stapar in the year 2013 and 2015, there was a necessity for a long-term loan for financing permanent working capital.

Enterprise Agroplod Stapar has lower gross margin in relation to PP Ratkovo, which in 2015 had minor drop from $30 \%$ to $28 \%$. Net margin is also below the net margin of an enterprise which can cover fixed and working assets with own capital, and net profit has also dropped in 2015 from $11 \%$ to $9.5 \%$.

It can be stated that in some noticeable portion, the amount of paid financial obligations, influenced this situation.

About liquidity, change in the structure of financing had a negative influence, so that quick liquidity ratio had dropped from 0.6 in the year 2014 to 0.18 in the year 2015 .

Table 3. Analysis of short balance sheet of Agroplod Stapar

\begin{tabular}{|l|r|r|r|}
\hline \multicolumn{1}{|c|}{ YEAR } & \multicolumn{1}{c|}{$\mathbf{2 0 1 3}$} & \multicolumn{1}{c|}{$\mathbf{2 0 1 4}$} & \multicolumn{1}{c|}{$\mathbf{2 0 1 5}$} \\
\hline FIXED ASSETS & 504,732 & 558,448 & 554,776 \\
\hline WORKING CAPITAL & 164,760 & 330,461 & 201,302 \\
\hline Inventories & 115,355 & 160,242 & 169,246 \\
\hline material, spare parts, tools and inventories & 16,416 & 8,450 & 17,187 \\
\hline production in progress and service in progress & 21,287 & 27,402 & 20,611 \\
\hline other inventories & 77,652 & 124,390 & 131,448 \\
\hline Other working capital & 49,405 & 170,219 & 32,056 \\
\hline DEFERED TAX ASSETS & 216,759 & 205,539 & 198,257 \\
\hline \multicolumn{1}{|c|}{ Total assets } & $\mathbf{8 8 6 , 2 5 1}$ & $\mathbf{1 , 0 9 4 , 4 4 8}$ & $\mathbf{9 5 4 , 3 3 5}$ \\
\hline EQUITY Total equity and liabilities & 493,807 & 555,849 & 598,588 \\
\hline LONG-TERM PROVISIONS AND LIABILITIES & 246,031 & 253,477 & 178,221 \\
\hline SHORT-TERM LIABILITIES & 146,413 & 285,122 & 177,526 \\
\hline
\end{tabular}

Source: Balance sheet of the Agroplod Stapar, for the period of 2013-2015. 
Graph 2. Analysis of asset and liabilities structure of Agroplod Stapar

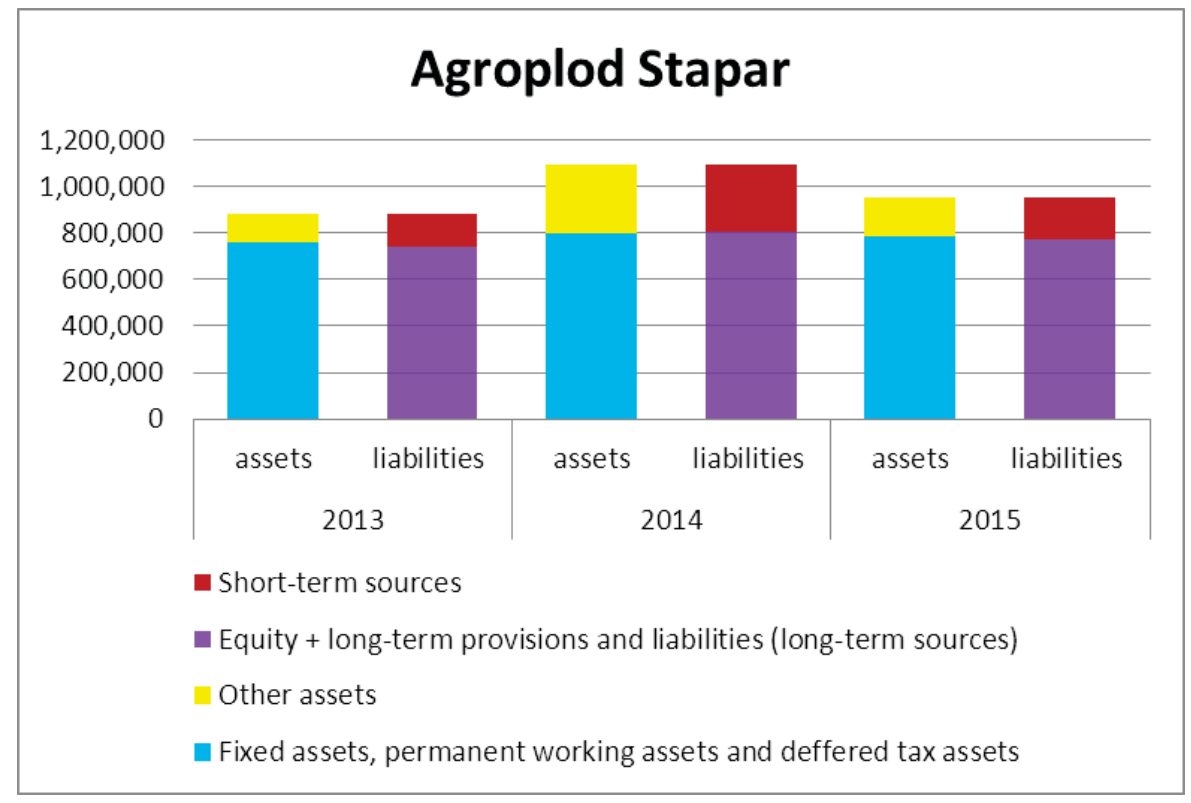

Source: Work of authors.

Enterprise Agroofice Bački Brestovac had also, during the observed period, closure of perennial investment cycle, which reflects in constant increase of fixed assets with the retain of the working capital on acertain level with the continuous attempt of adjusting the source of financing to asset structure.

In the year 2013 own capital did not cover fixed asset, and huge deficiency of long-term sources was compensated with financing through prolongation of short-term liabilities toward suppliers and through short-term bank loans.

This enterprise, encouraged with high profitability in the year 2013, has begun investment from short-term sources of financing which has further impaired already unfavourable financing source structure. Negative outcomes of this financing structure have continued in the year 2014 and 2015 (extreme decrease in profitability of this enterprise through gross and net profit). In the year 2014, even with a capitalization of achieved profit from the previous year and converting short-term liabilities in long-term liabilities, this enterprise did not manage to cover fixed assets from long-term sources, while entire long-term investment and minimum permanent working capital were covered from short-term sources.

In year 2015, this enterprise had significant discrepancy between working capital and fixed assets (fixed asset was increased during two years for more than a third, and working capital decreased, especially permanent working capital, or work in progress), which has directly influenced in reduction of total income of this enterprise, almost by a third. Even with the reduction of the total income, this enterprise has managed to increase net profit in relation to aprevious year, thanks to savings and larger reduction of other business expenses. This net profit was retained as a permanent source, a portion of retained profit was also turned into 
equity, and an increase of fixed assets in sources was covered with the conversion of shortterm borrowed sources into long-term loans toward banks. This trend has affected positively on liquidity ratio of this enterprise so that current liquidity increased from 0,7 to 1 , and quick liquidity ratio from 0.18 to 0.28 . In the year 2015 , the profitability of this enterprise has also recorded a positive trend in relation to a previous year. Gross margin has increased in the year 2015 from $28 \%$ to $32 \%$, EBITDA from $9 \%$ to $14 \%$ and net margin from $4 \%$ to $6 \%$.

Thanks to the improvement in financial mix and using own sources of financing and covering permanent working capital with long-term sources it is noticeable that this enterprise has achieved favourable business indicators, but still has not reached more stable structured enterprises.

The somewhat favourable structure of financing was achieved with conversion the portion of short-term loans into long-term, but at the same time has disrupted the structure of relation between fixed assets and working capital (on the expense of the latter), which means that the enterprise has most of the working capital converted into fixed assets.

Table 4. Analysis of short balance sheet of Agrooffice Bački Brestovac

\begin{tabular}{|c|c|c|c|}
\hline YEAR & 2013 & 2014 & 2015 \\
\hline FIXED ASSETS & 698,179 & 865,977 & 930,115 \\
\hline WORKING CAPITAL & 344,938 & 339,646 & 333,597 \\
\hline Inventories & 239,058 & 253,481 & 241,946 \\
\hline material, spare parts, tools and inventories & 3,052 & 3,443 & 19,043 \\
\hline production in progress and service in progress & 99,861 & 173,307 & 38,355 \\
\hline other inventories & 136,145 & 76,731 & 184,548 \\
\hline Other working capital & 105,880 & 86,165 & 91,651 \\
\hline DEFERED TAX ASSETS & 95,510 & 86,104 & 74,751 \\
\hline Total assets & $1,138,627$ & $1,291,727$ & $1,338,463$ \\
\hline EQUITY & 437,025 & 549,439 & 615,944 \\
\hline LONG-TERM PROVISIONS AND LIABILITIES & 169,349 & 265,867 & 396,958 \\
\hline SHORT-TERM LIABILITIES & 532,253 & 476,421 & 325,561 \\
\hline Total equity and liabilities & $1,138,627$ & $1,291,727$ & $1,338,463$ \\
\hline
\end{tabular}

Source: Balance sheet of the Agroofice Bački Brestovac, for the period of 2013-2015. 
Graph 3. Analysis of asset and liabilities structure of Agrooffice Bački Brestovac

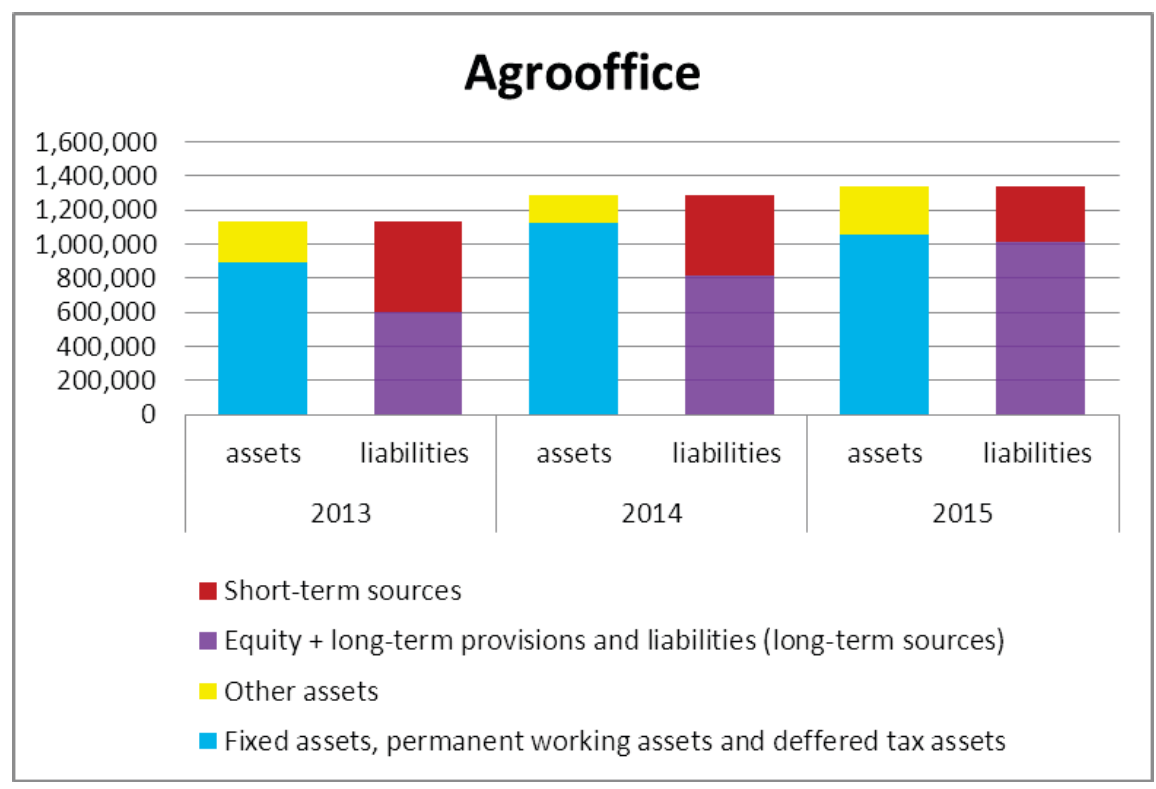

Source: Work of authors.

Our recommendation for this enterprise, to improve profitability and liquidity, is to increase working capital, especially the permanent working capital, and that should be covered with long-term sources of financing.

It also should be noted that the financial results of research conducted are higher than typical average in agriculture in Vojvodina. Vukoje and Milić point out that agricultural enterprises in Vojvodina are characterized by very low profitability, less than 5\% (2009, p. 164).

\section{Conclusion}

Results of the research show that in primary agricultural production, next to standard long-term investment loans and short-term loans for investment in agricultural production, there is a necessity for financing in the permanent working capital which could assist continuity of production process and enable conditions for more profitable business in agriculture.

By using permanent working capital with enterprises which don't have enough own or borrowed long-term sources it will reduce negative effects of product sale in the uncertain period and commodity retention in medium enterprises of primary agricultural production with large suppliers. Commodity exchange observed so far, usually benefits large manufacturers or traders. Also, it should be noted that small and medium agricultural enterprises use short-term sources under supremely adverse commercial terms.

Our recommendation is that state and other creditors should with more favorable loans for permanent working capital with longer maturity and favorable interest rates with adequate 
collateral provide small and medium enterprises which cannot cover fixed assets, long-term investments and portion of inventories (material, spare part and production in progress) with own capital and long-term obligation, thus help them establish preferable source of financing structure. Based on conducted research, we came to the conclusion that small and medium enterprises which have invested in fixed asset on the burden of working capital have the problem of decreased liquidity and profitability.

Each investment represents in certain measure disruption of existing financial mix, which requires readjustment of sources of financing (this presents a problem especially to agricultural enterprises, due to its specificity). With new structuring, the focus should be that long-term sources of financing can cover fixed assets and long-term investment, and also a portion of working capital which is necessary for continued investment in primary agricultural production.

The method of financing permanent working capital affects the profitability of agricultural enterprises. Based on the research, we concluded that enterprise which covers its permanent working capital from own sources, also achieves better profitability, while in enterprises that don't have long-term coverage for permanent working asset but instead covers it with borrowed (extraneous) sources, especially short-term sources, this situation reflects negatively on profitability which confirms the general hypothesis.

\section{Bibliography}

1. Amarender, R. (2013): Farm profitability and labor use efficiency, Indian Journal of Dryland Agricultural Research Development, Vol. 28, No. 2, pp. 1-21, The Indian Society of Dryland Agriculture, Hyderabad, Andhra Pradesh, India.

2. Babović, J., Veselinović, B. (2010): Agrarna politika EU i prilagođavanje agrara Srbije, Društveni izazovi evropskih integracija - Srbija i uporedna iskustva, Fakultet za pravne i poslovne studije, Novi Sad, Srbija, pp. 195-206.

3. Butzer, R., Mundlak, Y., Larson, D. F. (2010): Measures offixed capital in agriculture, World Bank Policy Research Working Paper Number 5472, pp. 1-39.

4. Chukwunweike, E. (2014): The impact of liquidity on profitability of some selected companies: the financial statement analysis (FSA) approach, Research Journal of Finance and Accounting, vol. 5, no. 5, pp. 81-90, The International Institute for Science, Technology and Education (IISTE), USA.

5. Daidone, S.,Anriquez, D. (2011): An extended cross-country database for agricultural investment and capital, ESA Working Paper No. 11-16, FAO, Rome, pp. 1-67.

6. Detre, D., Mishra, A. (2012): Drivers of agricultural profitability in the USA: an application of the Du Pont expansion method, Agricultural Finance Review, Vol. 72, No. 3, pp. 325-340, Emerald Group Publishing, Bingley, United Kingdom.

7. Katchova, A. (2010): An analysis of the financial performance of beginning farmers, Agricultural and Applied Economics Association, Annual Meeting, Denver, Colorado, pp 1-15. 
8. Mishra, A., Moss, C., Erickson, K. (2009): Regional differences in agricultural profitability, government payments, and farmland values: implications of DuPont expansion, Agricultural Finance Review, Vol. 69, No. 1, pp. 49-66, Emerald Group Publishing, Bingley, United Kingdom.

9. Obrenović, D., Vukoje, V. (2001): Analiza finansijskog rezultata i finansijskog položaja poljoprivrednih preduzeća Vojvodine, Agroekonomika, No. 29, pp. 46-64.

10. O'Donnell, C. (2010): Measuring and decomposing agricultural productivity and profitability change, Australian Journal of Agricultural and Resource Economics, Vol. 54, No. 4, pp. 527-560, Australian Agricultural and Resource Economics Society Inc, Canberra, Australia.

11. Paraušić, V., Cvijanović, J., Mihailović, B. (2013): Market analysis of clusters in Serbian agribusiness, Ekonomika poljoprivrede, Vol. 60, No. 4, pp. 713-728, Naučno društvo agrarnih ekonomista Balkana, Beograd; Institut za ekonomiku poljoprivrede, Beograd, Akademija ekonomskih nauka, Bukurešt.

12. Petrick, M., Kloss, M. (2012): Drivers of agricultural capital productivity in selected EU member states, Factor Markets Working Paper No. 30, pp. 1-44.

13. Račić, Ž., Barjaktarović, L., Zeremski, A. (2011): Analysis of indebtedness impact on the profitability of successful domestic companies in the financial crisis, Industrija, Vol. 39, No. 3, pp. 45-60, Ekonomski institut, Beograd, Srbija.

14. Veselinović, B., Drobnjaković, M. (2014): Qualitative and quantitative analysis of micro and macro aspects of agricultural finance, Ekonomika poljoprivrede, Vol. 61, No. 3, pp. 771-787, Naučno društvo agrarnih ekonomista Balkana, Beograd; Institut za ekonomiku poljoprivrede, Beograd, Akademija ekonomskih nauka, Bukurešt.

15. Vučković, B. (2013): Uporedna analiza poslovanja preduzeća iz agrarnog sektora, Ekonomija - teorija i praksa, Vol. 6, No. 2, pp. 18-33, Fakultet za ekonomiju i inženjerski menadžment u Novom Sadu, Novi Sad, Srbija.

16. Vučković, B. (2014): Značaj pojedinih indikatora poslovanja određenim grupama analitičara, Ekonomija - teorija i praksa, Vol. 7, No. 1, pp. 19-49, Fakultet za ekonomiju i inženjerski menadžment u Novom Sadu, Novi Sad, Srbija.

17. Vučković, B., Veselinović, B., Drobnjaković, M. (2016): Analysis of profitability of selected agricultural enterprises in the autonomous province of Vojvodina, Republic of Serbia, Actual Problems of Ecomomics, Vol. 176, No. 2, pp. 147-159, National Academy of Management, Kyiv, Ukraine.

18. Vučković, B. (2016): Causes of different profitability of agricultural sector, Ekonomika poljoprivrede, Vol. 63, No. 1, pp. 123-142, Naučno društvo agrarnih ekonomista Balkana, Beograd; Institut za ekonomiku poljoprivrede, Beograd, Akademija ekonomskih nauka, Bukurešt.

19. Vučković, B. (2016): Finansijski položaj i profitabilnost poljoprivrednih preduzeća, Ph.D. dissertation, Faculty of Economics and Engineering Management, University Business Academy in Novi Sad, Novi Sad, Serbia. 
20. Vukoje, V., Milić, D. (2009): The analysis of profitability of agricultural enterprises in Vojvodina (2003-2007), Časopis za procesnu tehniku i energetiku u poljoprivredi, Vol. 13, No. 2, pp. 162-165.

21. Vukoje, V., Zekić, V. (2010): Ekonomski položaj poljprivrednih preduzeća u Vojvodini (2001-2009), Ekonomika poljoprivrede, Vol. 57, No. 3, pp. 411-424, Naučno društvo agrarnih ekonomista Balkana, Beograd; Institut za ekonomiku poljoprivrede, Beograd, Akademija ekonomskih nauka, Bukurešt.

22. Agencija za privredne registre: www.apr.gov.rs

23. Narodna banka Srbije: www.nbs.rs

\section{FINANSIRANJE TRAJNIH OBRTNIH SREDSTAVA U POLJOPRIVREDI ${ }^{5}$}

\section{Branko Vučkovićc ${ }^{6}$, Branislav Veselinović ${ }^{7}$, Maja Drobnjaković ${ }^{8}$ \\ Rezime}

U ovom radu izvršen je pokušaj da se predoči problem uspostavljanja adekvatne strukture finansiranja srednjih poljoprivrednih preduzeća i da se ukaže na potrebu za trajnim obrtnim sredstvima u onim poljoprivrednim preduzećima koja sopstvenim kapitalom i dugoročnim izvorima finansiranja ne uspevaju da pokriju stalnu imovinu, dugoročne plasmane $i$ deo zaliha (materijal i rezervni delovi, proizvodnja u toku). U svrhu procene adekvatne strukture finansiranja srednjih poljoprivrednih preduzeća, koristićemo jedan od najpopularnijih metoda, kao što je studija slučaja i racio analiza. Rezultati istraživanja ukazuju na to da su u primarnoj poljoprivrednoj proizvodnji, pored standardnih investicionih dugoročnih kredita i kratkoročnih kredita za ulaganja u poljoprivrednu proizvodnju, neophodna i finansiranja u trajna obrtna sredstva zahvaljujući kojima bi se potpomogao kontinuitet procesa proizvodnje $i$ omogućili uslovi za profitabilnije poslovanje u poljoprivredi. Trebalo bi naglasiti $i$ to da se realna $i$ knjigovodstvena vrednost ovog nivoa trajnih obrtnih sredstava značajno međusobno razlikuju.

Ključne reči: poljoprivreda, finansiranje, trajna obrtna sredstva, trajne zalihe, profitabilnost.

5 Ovaj rad predstavlja nastavak istraživanja baziranog na doktorskoj disertaciji pod nazivom "Finansijski položaj i profitabilnost poljoprivrednih spreduzeća", koja je obuhvatala period 2009-2013. godine (Vučković, 2016).

6 Dr Branko Vučković, Vojvođanska banka NBG Group, Sombor, Ulica Sonje Marinković br. 1-3, 25000 Sombor, Srbija, Telefon: +381 25465 000, E-mail: vule.sombor@gmail.com

7 Redovni profesor, dr Branislav Veselinović, Univerzitet Privredna akademija, Fakultet za ekonomiju i inženjerski menažment, Cvećarska ulica br. 2, 21000 Novi Sad, Srbija, Telefon: +381 21400 484, E-mail: brane1952@gmail.com

8 Maja Drobnjaković M.A., diplomirani ekonomista, asistent, Univerzitet Privredna akademija, Fakultet za ekonomiju i inženjerski menažment, Cvećarska ulica br. 2, 21000 Novi Sad, Srbija, Telefon: +381 21400 484, E-mail: majadnovisad@gmail.com 